\title{
Technology is not a Barrier: A Survey of Energy System Technologies Required for Innovative Electricity Business Models Driving the Low Carbon Energy Revolution
}

\author{
Christoph Mazur ${ }^{1,2, * \mathbb{C}}$, Stephen Hall ${ }^{3}$, Jeffrey Hardy ${ }^{2}$ and Mark Workman ${ }^{4}$ \\ 1 Chemical Engineering Department, Imperial College London, London SW7 2AZ, UK \\ 2 Grantham Institute-Environment and Climate Change, Imperial College London, London SW7 2AZ, UK; \\ jeff.hardy@imperial.ac.uk \\ 3 School of Earth and Environment, University of Leeds, Leeds LS2 9JT, UK; S.Hall@leeds.ac.uk \\ 4 Energy Systems Catapult, Birmingham B4 6BS, UK; mark.workman07@imperial.ac.uk \\ * Correspondence: christoph.mazur@imperial.ac.uk
}

Received: 26 November 2018; Accepted: 24 January 2019; Published: 29 January 2019

\begin{abstract}
Energy system decarbonisation and changing consumer behaviours will create and destroy new markets in the electric power sector. This means that the energy industry will have to adapt their business models in order to capture these pools of value. Recent work explores how changes to the utility business model that include digital, decentralised or service-based offers could both disrupt the market and accelerate low carbon transitions. However, it is unclear whether these business models are technologically feasible. To answer this question, we undertook an expert panel study to determine the readiness levels of key enabling technologies. The result is an analysis of what technologies may hinder electricity business model innovation and where more research or development is necessary. The study shows that none of the business models that are compatible with a low carbon power sector are facing technology barriers that cannot be overcome, but there is still work to be done in the domain of system integration. We conclude that, especially in the field of energy system coordination and operation, there is a need for comprehensive demonstration trials which can iteratively combine and test information and communications technology (ICT) solutions. This form of innovation support would require a new approach to energy system trials.
\end{abstract}

Keywords: technology review; electricity system; future service energy business models; technology readiness level; energy revolution

\section{Introduction}

In recent years, the electricity system of the United Kingdom underwent major changes. The drive toward a lower carbon mix, together with the digitalisation and decentralisation of the system [1] and changed consumer behaviour and expectations, are challenging all the aspects of traditional system operation (National Grid, 2018). This leads to a variety of different future transition pathways [2,3]. It is not clear yet whether the transition will lead to a more centralized CCS (carbon capture and storage) or nuclear-based system, or to a completely decentralized renewables-based system with expanded flexibility and changed consumer behaviour-to name just a few options [4,5].

What is clear is that a transition to any of these futures will create and destroy different types of values currently captured by energy market participants [4,5]. This means that current energy market players will have to change the way they operate in order to be able to capture these new values. 
To explore the effect these changes may have on the utility business model, the Utility 2050 project [4] studied what electricity system value pools there may be in 2050 [5], and how these could be captured through the help of novel business models in 2016. Business models are understood not as a financial proposition or profit model, but as a frameworks to understand, evaluate and compare how businesses create, deliver and capture value [6,7].

Energy markets are theoretically open to any form of business model that can satisfy license condition, but other markets, economies of scale, increasing competencies and efficiency returns $[8,9]$ led a few similar business to dominate,. In the energy market, the corporate volume sale utility became the incumbent model [2,10]. Recent works on energy business models address how pressures created in other parts of the energy system, e.g. technological change, climate change commitments and evolving consumer preferences, place pressure on incumbent business models to evolve [11,12].

These studies greatly improved our understanding of the co-evolving nature of business models with the rest of the energy system [13], but have done little to appraise or assess the bundle of technologies that either allow them to exist, or those upstream technologies that can accommodate them into the existing market. This is a problem because there is no system level assessment of whether technological readiness is a fundamental barrier to rapid system decarbonisation led by new utility business models.

This paper undertakes this assessment by matching extant and proposed technologies of a suite of innovative business models generated by a stakeholder coproduction exercise led by the Utility 2050 project. In summer 2016, the Utility 2050 project convened 40 stakeholders from the UK energy sector to generate a suite of 11 new utility business models that could accelerate system decarbonisation, address the changing demands of the sector and operate in a recognisable liberalised market. These 11 business models were shortlisted to five by selecting those which were most compatible with the UK case and the current stage of market liberalisation.

This paper describes how the technologies most critical for each business model were assessed by our expert panel study. Then, it provides an overview of the maturity of these technologies using the Technology Readiness Level (TRL) framework. Finally, it shows which of the technologies could hinder the realisation of the business model archetypes outlined in Section 2.2.

\section{Material and Methods}

In this study, we applied an iterative approach to identify the maturity of the technologies required for nontraditional business models (see Section 2.2) that may emerge in future energy systems. The technologies were derived from a set of novel business models that emerged from the stakeholder workshop described above. Technology needs for each business model were explicitly requested from workshop participants for each proposed business model suggested. These technology needs were extracted from workshop feedback and internal extrapolation. For each of these technologies, we used the Technology Readiness Level (TRL) (see Section 2.1) approach to determine the current maturity of the technologies. Similarly to Reddy and Painuly (2004) [14], we recruited an expert panel [15] of energy, electricity system stakeholders and researchers to undergo a process of assigning TRLs to the different technologies (see Section 2.3 for survey design and respondents). In contrast to past studies $[16,17]$ that looked into different types of barriers, this study focused on technological barriers only. Also, the expert panel paid particular attention in subsequent rounds of analysis to key enabling technologies in lower TRL bands. For these technologies, the panel also analysed how crucial each technology was as an enabling element of each discrete business model.

\subsection{Technology Readiness Levels}

The critical gap this study addresses is that, to our knowledge, there is no comparable assessment of the readiness of the basket of technologies needed to make novel future electricity utility business models work, as opposed to only those that enable a specific market function. There is no maturity overview on technologies for future energy systems and energy business models for electricity markets. 
Limited by time and resources and by confidentiality of the industry, this study fills this gap using an elite sampling expert panel approach.

In this study, we chose the TRL concept as the assessment tool for the technologies. Introduced by NASA in the 1970s, the TRL concept is a way to have a discipline-independent assessment and communication of the maturity of new technologies. In 1995, Mankins articulated the first definitions of all of the nine levels, with TRL 1 being "basic principles observed and reported" and TRL 9 "actual system 'flight proven' through successful mission operations" [18]. The concept was applied in many different segments and is well-understood in different disciplines [19]. In our study, we used the European Comission's Horizon 2020 working definitions [20]. To reduce complexity, we grouped the nine categories into three categories (see Table 1): Laboratory/Research (TRL 1-3), Demonstrator status (TRL 4-6) and Deployment status (TRL 7-9), with the latter being classes as a maturity in which roll out was largely dependent on exogenous market conditions.

Table 1. Technology Readiness Levels (TRL) categories provided to survey respondents (in comparison to EU Horizon 2020 categories).

\begin{tabular}{cl}
\hline $\begin{array}{c}\text { TRL Categories used for this } \\
\text { study's survey. }\end{array}$ & \multicolumn{1}{c}{ EU Horizon 2020 TRL categories [20] } \\
\hline \multirow{3}{*}{ 1-3 Laboratory/Research } & $\begin{array}{l}\text { TRL 1-basic principles observed } \\
\text { TRL 2-technology concept formulated } \\
\text { TRL 3-experimental proof of concept }\end{array}$ \\
\hline & TRL 4-technology validated in lab \\
& TRL 5-technology validated in relevant environment (industrially \\
& relevant environment in the case of key enabling technologies) \\
& TRL 6-technology demonstrated in relevant environment (industrially \\
4-6 Demonstrator status & relevant environment in the case of key enabling technologies) \\
& TRL 7-system prototype demonstration in operational environment \\
& TRL 8-system complete and qualified \\
& TRL 9-actual system proven in operational environment (competitive \\
& manufacturing in the case of key enabling technologies; or in space) \\
\hline 7-9 Deployment status
\end{tabular}

\subsection{Business Model Archetypes for the Future Energy System}

The technologies were identified based upon a set of business model archetypes produced by the Utility2050 project [4]. The attendees of the workshop were provided with a set of future energy scenarios, ranging from centralized CCS-based future to highly decentralized renewable-based scenarios based upon a past study [5].

Five business model archetypes were developed in detail in the workshop.

Low carbon generators, who focus on the building and provision of low carbon capacity (with potentially CCS) in order to sell the capacity or power directly to large customers or the wholesale market. This business model archetype is designed to address the wholesale and capacity markets directly. It has no consumer offer and focuses on winning subsidy payment, avoids carbon pricing, and operates an efficient wholesale model with some commercial to commercial direct contracting.

New Electrifiers, a 'volume sales' utility that is helping consumers switch to electric heat and mobility in order to significantly expand demand from commercial and domestic customers. It also includes installing equipment, such as storage or photovoltaic (PV) and automating Demand-side Response (DSR).

Energy Service Companies (ESCo), offers the ESCo value proposition to private consumers and delivers energy services to customers, such as comfort and illumination, rather than units of energy like a traditional supplier. The ESCo sources the residual energy demand from either its own generation or the wholesale market. Importantly, the utility may also lease the vehicle and battery through a single energy service bill and charge for annual mileage, utilising the vehicle battery to optimise the consumer's consumption for different outcomes, i.e. low carbon or least cost. There is strong DSM 
capability and the majority of balancing services move to demand response through vehicle to grid and appliance based demand side management.

Peer-to-Peer Trading allows customers to directly buy, sell or swap electricity with each other.

Third Party Controllers, similar to the ESCo, but also bundles all other utility services (water, communication, etc.) combined with switching between services on-behalf of the customer.

These five business model archetypes [4] are outlined Figure 1.

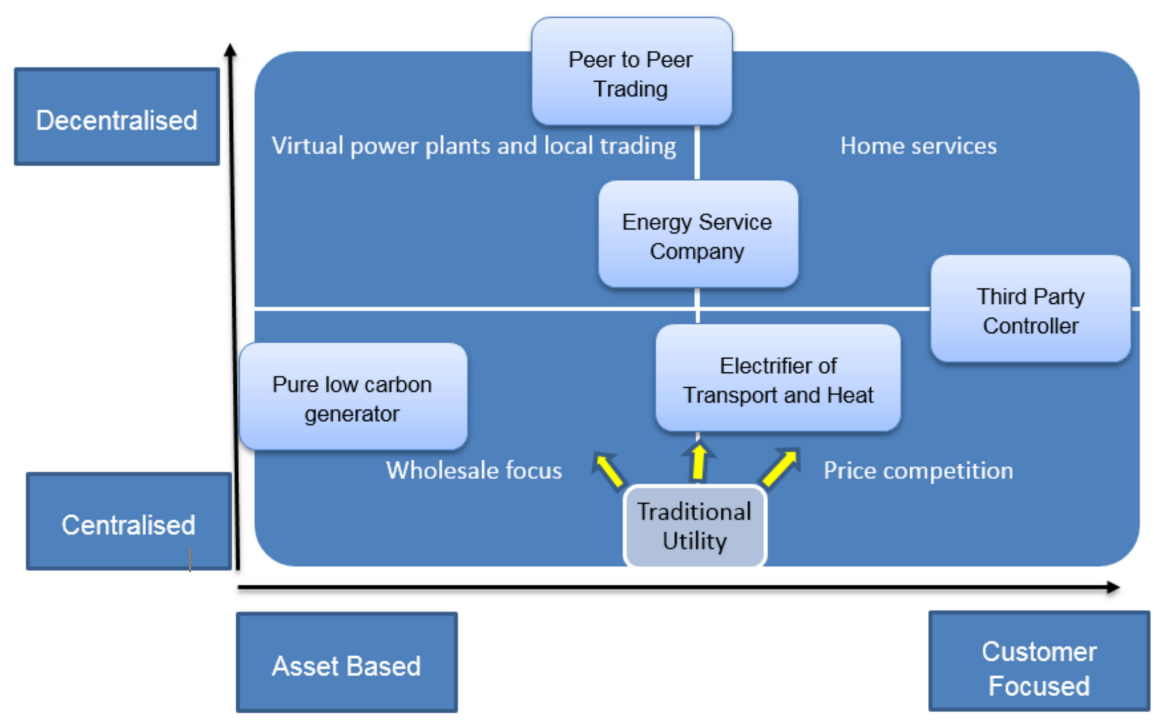

Figure 1. Future Business Models.

\subsection{The Expert Panel and Survey Design}

We constructed an expert panel from UK stakeholders (see Table 2) to inform an iterative survey approach. The expert panel method is particularly suited to foresight situations, in which a complex problem with uncertain boundaries is in question, where credibility of personal judgement is important and with whom a medium term discursive or iterative process is desirable. The panel was presented with an enabling technologies matrix (see Tables 3-5), and asked to execute the following tasks:

1. Where they have knowledge on the technology, assign one of the three TRL category (see the categories in Table 1) for the technologies in Tables 3-5. For technologies out of their scope we asked to provide no input.

2. Where TRL category $1-3$ or $4-6$ was selected, we asked them to assess how the level of difficulty to get the technologies to TRL 7-9 and to comment on this. The panel was asked to mark the barriers as "low," "medium" or "high," and to clarify the barrier. The clarification ensured that the respondents did not assign TRL levels based upon non-technology aspects

We then gathered the responses and collated the inputs for all of the technologies in the three TRL categories.

This elite sampling method allowed us to investigate TRL from an informed cross section of the sector. Finally, we linked these technologies back to the business model archetypes to outline which of the technologies and solutions that are not yet ready for deployment need further work and development, or at least deployment.

Our expert panel was asked to limit their assessment to pure technology readiness and were explicitly informed not to consider cost, policy compatibility or regulatory limitations. This is specifically to represent the technology enablers of innovative business models which in themselves are market destabilising and, therefore, reflecting on issues outside the ability of the technology to work in its intended situation would be unhelpful to the stated question of this study. 
This study aimed to explore the pivotal nature of the engineering and ICT required for low-carbon utility business models, not how the business models perform within a given power market. The only criterion under consideration was whether the technology was already deployed anywhere successfully, either in Research and Development (R\&D), subsidised trial or near-market applications. This study aimed to capture whether the technology was already deployed on a reasonable scale or whether it was still in the R\&D stage. Clearly, this provides a space for different interpretations. Therefore, we invited a variety of experts to take part in this survey (see Table 2) to mitigate this risk. We also acknowledge that the sample of experts may be limited. However, it represents high-level engagement from an elite audience in a medium-term research process. In a future work, the panel may be expanded to a wider membership.

Table 2. Overview of experts who contributed to the technology survey.

\begin{tabular}{lc}
\hline $\begin{array}{l}\text { Technical Lead in energy optimisation and integration of } \\
\text { renewable energy }\end{array}$ & $\begin{array}{c}\text { Industry (EU, Large enterprise in } \\
\text { power systems) }\end{array}$ \\
\hline $\begin{array}{l}\text { CTO of company in the domain of smart grid technology, control, } \\
\text { storage and grid services }\end{array}$ & $\begin{array}{c}\text { Industry (UK SME in smart } \\
\text { grid tech) }\end{array}$ \\
\hline $\begin{array}{l}\text { Energy Engineer with expertise in energy systems, heat pumps, } \\
\text { Combined Heat and Power (CHP) and energy services }\end{array}$ & $\begin{array}{c}\text { Industry (UK Large Enterprise in } \\
\text { engineering consultancy) }\end{array}$ \\
\hline $\begin{array}{l}\text { Smart Grid Analyst and expert in Smart Grids, renewable energy, } \\
\text { energy markets, and network transition }\end{array}$ & $\begin{array}{c}\text { Industry (UK SME in smart } \\
\text { grid Solutions) }\end{array}$ \\
\hline $\begin{array}{l}\text { Principal Sustainability Advisor and Build Environment Energy expert } \\
\text { Senior Manager in Sustainable Energy, and expert in decentralized } \\
\text { energy systems }\end{array}$ & Institute in Buildings (UK) \\
\hline $\begin{array}{l}\text { Research Fellow in Smart and Sustainable District, decentralized energy } \\
\text { systems, smart meter solutions and ICT infrastructures }\end{array}$ & Municipality (UK) \\
\hline $\begin{array}{l}\text { Research Fellow in statistical learning and control for electricity grids. } \\
\text { Smart Grid technologies }\end{array}$ & Academia (UK) \\
\hline $\begin{array}{l}\text { Professor in urban systems, energy systems and technologies and } \\
\text { infrastructures }\end{array}$ & Academia (UK) \\
\hline $\begin{array}{l}\text { Reader in Clean Energy Processes and expert in energy efficiency and } \\
\text { renewable technologies }\end{array}$ & Academia (UK) \\
\hline $\begin{array}{l}\text { Research Fellow in Energy Systems and the Built Environment. Expert } \\
\text { in energy management in non-domestic and domestic sectors }\end{array}$ & Academia (UK) \\
\hline $\begin{array}{l}\text { Senior lecturer in energy systems models and energy technology, } \\
\text { infrastructure, economics and the environment. }\end{array}$ & Academia (UK) \\
\hline $\begin{array}{l}\text { Research Fellow in economics and policy for Climate Change } \\
\text { Mitigation Technologies }\end{array}$ & Academia (UK) \\
\hline & Academia (UK) \\
\hline
\end{tabular}

\section{Results}

In this section, we provide the results of our maturity assessment of technologies are key enablers for low-carbon business model innovation in the utility sector-here in the case of the electricity system. We split the technologies into three different groups: Supply-side technologies, demand-side technologies, and technologies that are needed in the domain of data, communication and integration. Where there are low levels of TRL and a need for further work, a more detailed description of the technology is provided.

\subsection{Technology Readiness Levels of Energy System Technologies}

\subsubsection{Supply Side Technologies}

Table 3 provides an overview of the supply technologies that have been outlined as the key technologies to enable the different business models. Most of them are technologies in the domain 
of generation of plant management. The results show that all technologies are seen to be at the stage where they can be widely deployed.

Table 3. TRLs of supply-side technologies.

\begin{tabular}{|c|c|c|c|}
\hline $\begin{array}{l}\text { Energy supply and } \\
\text { generation technologies } \\
\text { (Numbers indicate for which } \\
\text { business models these are } \\
\text { relevant: Low carbon generators } \\
\text { (1), New Electrifiers (2), Energy } \\
\text { Service Companies (3), Peer to } \\
\text { Peer platform (4), Third Party } \\
\text { Controllers (5). }\end{array}$ & $\begin{array}{c}\text { Explanation } \\
\text { (with literature reference for } \\
\text { not widely } \\
\text { known technologies) }\end{array}$ & $\begin{array}{c}\text { Technology Readiness } \\
\text { level (TRL) } \\
\text { (Colour Code outlines } \\
\text { TRL level) } \\
\text { 1-3 red } \\
4-6 \text { amber } \\
\text { 7-9 green }\end{array}$ & $\begin{array}{l}\text { Constraints/Barriers/Limits } \\
\text { to increase TRL to 7-9 } \\
\text { (Colour code illustrates how } \\
\text { easy to overcome) } \\
\text { simple—green } \\
\text { medium—amber } \\
\text { difficult_red }\end{array}$ \\
\hline $\begin{array}{l}\text { Stationary Batteries } \\
\qquad(1,2,3,4,5)\end{array}$ & $\begin{array}{l}\text { Large scale stationary storage } \\
\text { technologies connected to the } \\
\text { grid, to provide storage as } \\
\text { well as flexibility services. }\end{array}$ & 7-9 & $\begin{array}{c}\text { Not relevant as already highest } \\
\text { TRL range }\end{array}$ \\
\hline $\begin{array}{c}\text { Micro Combined Heat and } \\
\text { Power (CHP) } \\
(1,2,3,4,5)\end{array}$ & $\begin{array}{l}\text { Combined heat and power } \\
\text { generation for } \\
\text { residential applications [21] }\end{array}$ & $7-9$ & $\begin{array}{c}\text { Not relevant as already highest } \\
\text { TRL range }\end{array}$ \\
\hline $\begin{array}{l}\text { Solar PV } \\
(1,2,3,5)\end{array}$ & - & $7-9$ & $\begin{array}{c}\text { Not relevant as already highest } \\
\text { TRL range }\end{array}$ \\
\hline $\begin{array}{c}\text { Solar Thermal } \\
(1,2,3,5)\end{array}$ & - & 7-9 & $\begin{array}{c}\text { Not relevant as already highest } \\
\text { TRL range }\end{array}$ \\
\hline $\begin{array}{l}\text { Heat Storage } \\
(1,2,3,5)\end{array}$ & $\begin{array}{c}\text { Different types of heat storage } \\
\text { including Phase Change } \\
\text { Material (PCM) [21] }\end{array}$ & $7-9$ & $\begin{array}{c}\text { Not relevant as already highest } \\
\text { TRL range }\end{array}$ \\
\hline $\begin{array}{c}\text { Fuel Cells } \\
(1,2,3)\end{array}$ & ( & $7-9$ & $\begin{array}{c}\text { Not relevant as already highest } \\
\text { TRL range }\end{array}$ \\
\hline $\begin{array}{l}\text { Carbon Capture and Storage } \\
\text { (1) }\end{array}$ & - & $7-9$ & $\begin{array}{c}\text { Not relevant as already highest } \\
\text { TRL range }\end{array}$ \\
\hline $\begin{array}{l}\text { Synthetic Fuels } \\
\qquad(1,2,3)\end{array}$ & $\begin{array}{l}\text { Synthetic fuels that allow the } \\
\text { storage of electricity in other } \\
\text { chemical forms [22] }\end{array}$ & $7-9$ & $\begin{array}{c}\text { Not relevant as already highest } \\
\text { TRL range }\end{array}$ \\
\hline $\begin{array}{l}\text { District Heat Networks } \\
(1,2,3,5)\end{array}$ & $\begin{array}{c}\text { 4th generation } \\
\text { heat network [23] }\end{array}$ & $7-9$ & $\begin{array}{c}\text { Not relevant as already highest } \\
\text { TRL range }\end{array}$ \\
\hline $\begin{array}{l}\text { Gas Fired Power plants } \\
\qquad(1,2,3,5)\end{array}$ & 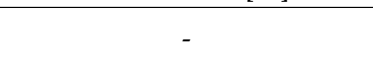 & $7-9$ & $\begin{array}{c}\text { Not relevant as already highest } \\
\text { TRL range }\end{array}$ \\
\hline $\begin{array}{c}\text { Diesel generators } \\
(1,2,3,5)\end{array}$ & - & $7-9$ & $\begin{array}{c}\text { Not relevant as already highest } \\
\text { TRL range }\end{array}$ \\
\hline $\begin{array}{c}\text { Interconnection (e.g. HVDC) } \\
(1,2,3,4,5)\end{array}$ & $\begin{array}{l}\text { High voltage direct current used } \\
\text { for interconnection and long } \\
\text { distance transmission [24] }\end{array}$ & $7-9$ & $\begin{array}{c}\text { Not relevant as already highest } \\
\text { TRL range }\end{array}$ \\
\hline $\begin{array}{c}\text { STATCOMs/SVCs } \\
(2,3,4,5)\end{array}$ & $\begin{array}{c}\text { Static synchronous } \\
\text { compensator (STATCOMS) to } \\
\text { provide grid stability from the } \\
\text { supply side [25] }\end{array}$ & 7-9 & $\begin{array}{c}\text { Not relevant as already highest } \\
\text { TRL range }\end{array}$ \\
\hline $\begin{array}{c}\text { SCADA equip. } \\
\text { (e.g. switches, sensors) } \\
(2,3,4,5)\end{array}$ & $\begin{array}{l}\text { Supervisory Control and Data } \\
\text { Acquisition (SCADA) to control } \\
\text { whole networks of power } \\
\text { generation assets, from a top } \\
\text { level down to the field level [26] }\end{array}$ & $7-9$ & $\begin{array}{c}\text { Not relevant as already highest } \\
\text { TRL range }\end{array}$ \\
\hline $\begin{array}{l}\text { Nuclear } \\
\text { (1) }\end{array}$ & 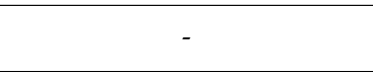 & $7-9$ & $\begin{array}{c}\text { Not relevant as already highest } \\
\text { TRL range }\end{array}$ \\
\hline $\begin{array}{l}\text { Wind } \\
(1)\end{array}$ & - & $7-9$ & $\begin{array}{c}\text { Not relevant as already highest } \\
\text { TRL range }\end{array}$ \\
\hline $\begin{array}{c}\text { Biomass supply chain } \\
\text { (1) }\end{array}$ & - & $7-9$ & $\begin{array}{c}\text { Not relevant as already highest } \\
\text { TRL range }\end{array}$ \\
\hline $\begin{array}{c}\text { Hydrogen Storage } \\
\text { (1) }\end{array}$ & $\begin{array}{l}\text { Large scale storage capabilities } \\
\text { for hydrogen [27] }\end{array}$ & $7-9$ & $\begin{array}{c}\text { Not relevant as already highest } \\
\text { TRL range }\end{array}$ \\
\hline $\begin{array}{l}\text { Hydrogen infrastructure } \\
\qquad(1,2,3,4,5)\end{array}$ & 型 & $7-9$ & $\begin{array}{c}\text { Not relevant as already highest } \\
\text { TRL range }\end{array}$ \\
\hline $\begin{array}{c}\text { Combined Heat and } \\
\text { Power (CHP) } \\
(2,3,4,5)\end{array}$ & - & 7-9 & $\begin{array}{c}\text { Not relevant as already highest } \\
\text { TRL range }\end{array}$ \\
\hline
\end{tabular}




\subsubsection{Demand-Side Technologies Enabling Energy Service Models}

Like the supply-side technologies, the demand-side technologies (see Table 4) are mainly in the domain of smart appliances or energy efficiency. All technologies are seen to be at the stage where they can be widely deployed.

Table 4. TRLs of demand-side technologies.

\begin{tabular}{|c|c|c|c|}
\hline $\begin{array}{l}\text { Demand side technologies } \\
\text { (Numbers indicate for which } \\
\text { business models these are } \\
\text { relevant: Lowcarbon } \\
\text { generators (1), New } \\
\text { Electrifiers (2), Energy Service } \\
\text { Companies (3), Peer to Peer } \\
\text { platform (4), Third Party } \\
\text { Controllers (5). }\end{array}$ & $\begin{array}{c}\text { Explanation } \\
\text { (with literature reference for } \\
\text { not widely known } \\
\text { technologies) }\end{array}$ & $\begin{array}{c}\text { Technology Readiness } \\
\text { level (TRL) } \\
\text { (Colour Code outlines } \\
\text { TRL level) } \\
\text { 1-3 red } \\
\text { 4-6 } \text { amber } \\
\text { 7-9 green }\end{array}$ & $\begin{array}{c}\text { Constraints/Barriers/Limits } \\
\text { to increase TRL to 7-9 } \\
\text { (Colour code illustrates how } \\
\text { easy to overcome) } \\
\text { simple—green } \\
\text { medium—amber } \\
\text { difficult_red }\end{array}$ \\
\hline $\begin{array}{c}\text { Heat Pumps } \\
(2,3,5)\end{array}$ & For the electrification of heat & $7-9$ & $\begin{array}{c}\text { Not relevant as already highest } \\
\text { TRL range }\end{array}$ \\
\hline $\begin{array}{c}\text { Remote controlled Electric } \\
\text { storage heaters } \\
(2,3,5)\end{array}$ & $\begin{array}{l}\text { For the storage of heat and } \\
\text { its control }\end{array}$ & $7-9$ & $\begin{array}{c}\text { Not relevant as already highest } \\
\text { TRL range }\end{array}$ \\
\hline $\begin{array}{c}\text { Energy Efficient Lightning } \\
(1,2,3,5)\end{array}$ & $\begin{array}{l}\text { For efficiency improvement } \\
\text { driven business models }\end{array}$ & $7-9$ & $\begin{array}{l}\text { Not relevant as already highest } \\
\text { TRL range }\end{array}$ \\
\hline $\begin{array}{c}\text { Intelligent heating controllers } \\
(2,3,5)\end{array}$ & For control of heat demands & $7-9$ & $\begin{array}{c}\text { Not relevant as already highest } \\
\text { TRL range }\end{array}$ \\
\hline $\begin{array}{l}\text { In-home displays } \\
\qquad(2,3,4,5)\end{array}$ & $\begin{array}{l}\text { For business models that } \\
\text { require human interaction } \\
\text { and response }\end{array}$ & $7-9$ & $\begin{array}{c}\text { Not relevant as already highest } \\
\text { TRL range }\end{array}$ \\
\hline $\begin{array}{c}\text { Smart appliances } \\
(1,2,3,4,5)\end{array}$ & For Demand-Side Response & $7-9$ & $\begin{array}{l}\text { Not relevant as already highest } \\
\text { TRL range }\end{array}$ \\
\hline $\begin{array}{c}\text { Smart EV Chargers } \\
(1,2,3,4,5)\end{array}$ & $\begin{array}{l}\text { For the electrification } \\
\text { of transport }\end{array}$ & $7-9$ & $\begin{array}{c}\text { Not relevant as already highest } \\
\text { TRL range }\end{array}$ \\
\hline $\begin{array}{l}\text { Hydrogen Vehicles } \\
\text { (1) }\end{array}$ & $\begin{array}{l}\text { As one alternative for the } \\
\text { electrification of transport }\end{array}$ & $7-9$ & $\begin{array}{c}\text { Not relevant as already highest } \\
\text { TRL range }\end{array}$ \\
\hline $\begin{array}{c}\text { Hybrid Vehicles } \\
(1,2,3,5)\end{array}$ & $\begin{array}{l}\text { As one alternative for the } \\
\text { electrification of transport }\end{array}$ & $7-9$ & $\begin{array}{c}\text { Not relevant as already highest } \\
\text { TRL range }\end{array}$ \\
\hline $\begin{array}{l}\text { Electric Vehicles } \\
\qquad(1,2,3,5)\end{array}$ & $\begin{array}{l}\text { As one alternative for the } \\
\text { electrification of transport }\end{array}$ & $7-9$ & $\begin{array}{c}\text { Not relevant as already highest } \\
\text { TRL range }\end{array}$ \\
\hline
\end{tabular}

\subsubsection{Data and Energy System Integration Technologies Enabling Energy Service Models}

In the case of Data and Energy Systems Integration (see Table 5), most of the technologies are at a stage where they can be deployed. However, according to the expert panel assessment, there are a number of technologies that still require further demonstrator projects before they can be widely deployed.

Table 5. TRLs of Data and Energy System Integration Technologies.

\begin{tabular}{|c|c|c|c|}
\hline Technologies & & (A) & (B) \\
\hline (Numbers indicate for which & & Technology Readiness & Constraints/Barriers/Limits \\
\hline business models these are & & level (TRL) & to increase TRL to 7-9 \\
\hline relevant: Low carbon generators & Explanation & (Colour Code outlines & (Colour code illustrates how \\
\hline (1), New Electrifiers (2), Energy & Explanation & TRL level) & easy to overcome) \\
\hline Service Companies (3), Peer to & & 1-3 red & simple-green \\
\hline Peer platform (4), Third Party & & 4-6 amber & medium-amber \\
\hline Controllers (5). Crucial in bold & & 7-9 green & difficult-red \\
\hline $\begin{array}{c}\text { Smart Meter Technologies } \\
\mathrm{S}(1,2,3,4,5)\end{array}$ & - & $7-9$ & $\begin{array}{c}\text { Not relevant as already highest } \\
\text { TRL range }\end{array}$ \\
\hline $\begin{array}{c}\text { Home Energy Management } \\
\text { Systems (HEMS) } \\
(2,3,4,5)\end{array}$ & $\begin{array}{l}\text { Operation of home energy } \\
\text { assets with respect to use } \\
\text { and market [28] }\end{array}$ & $7-9$ & $\begin{array}{c}\text { Not relevant as already highest } \\
\text { TRL range }\end{array}$ \\
\hline $\begin{array}{c}\text { Building Energy Management } \\
\text { Systems (BEMS) } \\
(2,3,4,5)\end{array}$ & $\begin{array}{l}\text { Operation of building energy } \\
\text { assets with respect to use } \\
\text { and market [29] }\end{array}$ & $7-9$ & $\begin{array}{c}\text { Not relevant as already highest } \\
\text { TRL range }\end{array}$ \\
\hline $\begin{array}{c}\text { Demand-Side Response } \\
(1,2,3,4,5)\end{array}$ & $\begin{array}{c}\text { Flexible control of demand to } \\
\text { match available supply [30] }\end{array}$ & $7-9$ & $\begin{array}{l}\text { Not relevant as already highest } \\
\text { TRL range }\end{array}$ \\
\hline
\end{tabular}


Table 5. Cont.

\begin{tabular}{|c|c|c|c|}
\hline $\begin{array}{l}\text { Sensors (IoT) } \\
\quad(2,3,5)\end{array}$ & $\begin{array}{l}\text { Different Internet of Things } \\
\text { capable sensors necessary to } \\
\text { monitor the state of the } \\
\text { different energy assets }\end{array}$ & 7-9 & $\begin{array}{c}\text { Not relevant as already highest } \\
\text { TRL range }\end{array}$ \\
\hline $\begin{array}{l}\text { Vehicle-to-Grid Communication } \\
\text { (V2G) }\end{array}$ & & 7-9 & $\begin{array}{c}\text { Not relevant as already highest } \\
\text { TRL range }\end{array}$ \\
\hline $\begin{array}{l}\text { Communication for } \\
\text { Wholesale market }\end{array}$ & $\begin{array}{l}\text { Communication for real-time } \\
\text { electricity markets [31] }\end{array}$ & $4-6$ & medium \\
\hline Cyber security & 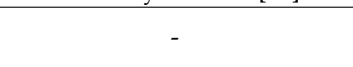 & 7-9 & $\begin{array}{c}\text { Not relevant as already highest } \\
\text { TRL range }\end{array}$ \\
\hline Blockchain & - & 7-9 & $\begin{array}{l}\text { Not relevant as already highest } \\
\text { TRL range }\end{array}$ \\
\hline Peer-to-peer communication & - & $7-9$ & $\begin{array}{c}\text { Not relevant as already highest } \\
\text { TRL range }\end{array}$ \\
\hline Reactive Power Control & [32] & $7-9$ & $\begin{array}{l}\text { Not relevant as already highest } \\
\text { TRL range }\end{array}$ \\
\hline Local Network Balancing & $\begin{array}{l}\text { Control technologies to } \\
\text { balance of Supply and } \\
\text { Demand on Distribution } \\
\text { Network Level [33] }\end{array}$ & $7-9$ & $\begin{array}{c}\text { Not relevant as already highest } \\
\text { TRL range }\end{array}$ \\
\hline Peer-to-peer trading agents & $\begin{array}{l}\text { Automated participation in } \\
\text { peer-to-peer markets [34] }\end{array}$ & $4-6$ & medium \\
\hline Market/Trading platform & $\begin{array}{l}\text { Trading platforms that link } \\
\text { wide ranges of data and } \\
\text { traders-from retail to } \\
\text { wholesale }[34,35]\end{array}$ & 7-9 & $\begin{array}{c}\text { Not relevant as already highest } \\
\text { TRL range }\end{array}$ \\
\hline Trading Optimisation & $\begin{array}{l}\text { Holistic solutions for } \\
\text { optimisation of trading } \\
\text { combined with electricity } \\
\text { assets control [34] }\end{array}$ & $7-9$ & $\begin{array}{c}\text { Not relevant as already highest } \\
\text { TRL range }\end{array}$ \\
\hline Automated Payment Systems & 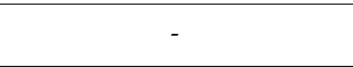 & 7-9 & $\begin{array}{l}\text { Not relevant as already highest } \\
\text { TRL range }\end{array}$ \\
\hline Car Sharing Systems & - & 7-9 & $\begin{array}{l}\text { Not relevant as already highest } \\
\text { TRL range }\end{array}$ \\
\hline $\begin{array}{c}\text { Advanced Distribution } \\
\text { Management System (ADMS) }\end{array}$ & $\begin{array}{l}\text { Software platform that } \\
\text { supports distribution } \\
\text { management and } \\
\text { optimization. }[36,37]\end{array}$ & $4-6$ & simple \\
\hline Machine-Learning & $\begin{array}{l}\text { General machine learning } \\
\text { technologies to improve } \\
\text { autonomous operation of } \\
\text { energy system }\end{array}$ & $7-9$ & $\begin{array}{c}\text { Not relevant as already highest } \\
\text { TRL range }\end{array}$ \\
\hline $\begin{array}{l}\text { Machine-to-Machine } \\
\text { Communications }\end{array}$ & $\begin{array}{c}\text { Communication between } \\
\text { energy assets to allow } \\
\text { cross-optimisation } \\
{[38]}\end{array}$ & $4-6$ & simple \\
\hline Generation Optimisation & $\begin{array}{l}\text { General optimisation of the } \\
\text { whole generation park }\end{array}$ & $4-6$ & medium \\
\hline Big/Data processing \& analysis & $\begin{array}{l}\text { General big data approaches } \\
\text { to improve operation of assets }\end{array}$ & $7-9$ & $\begin{array}{l}\text { Not relevant as already highest } \\
\text { TRL range }\end{array}$ \\
\hline $\begin{array}{l}\text { Wide-Area Energy Management } \\
\text { Systems (WAEMS) }\end{array}$ & $\begin{array}{c}\text { Systems that can manage and } \\
\text { optimise energy assets on a } \\
\text { district level [39] }\end{array}$ & $4-6$ & simple \\
\hline Virtual Power Plant (VPP) & $\begin{array}{l}\text { Aggregation of distributed } \\
\text { energy assets into one } \\
\text { virtual one [40] }\end{array}$ & $4-6$ & medium \\
\hline
\end{tabular}

According to our respondents, there are three technologies where the barriers can be easily overcome:

- Advanced Distribution Management Systems (ADMS): Software platform that supports distribution management and optimization [36]. There are already smaller trials that just need scaling up.

- Machine-to-Machine Communications: Communication between energy assets to allow cross-optimisation [38]. This type of technology is common in manufacturing, but has not been widely adopted to the energy sector yet.

- Wide-Area Energy Management Systems (WAEMS): Systems that can manage and optimise energy assets on a district level [39]. There are already smaller trials that just need scaling up. 


\section{Discussion}

These data show that there are very few barriers to business model innovation in the UK energy system posed by supply- and demand-side energy technologies. They also show that there are some moderate barriers to business model innovation posed by integrative ICT technologies, which at present, may be frustrating market entry or holding back business model innovation by remaining untrialed at scale.

Adopting this approach to technology assessment allows the research team to explore which technologies are holding back business model change, as opposed to assessing which individual technologies require cost reductions to enter the existing market. This is critical because the entry of new business models into an established market with substantial incumbent advantage puts technological niches at a price and scale disadvantage [41]. This suggests that there is an opportunity to pursue technological trials, which focus less on individual engineering innovation and more on combining and recombining ICT and systems integration tools to enable new business models to enter the energy market. Specifically, there were four themes of areas that can be drawn from the date in which more work is necessary to allow new business models to flourish:

- Communication for wholesale markets: This allows the communication of wholesale market information between any type of stakeholders, and also between wholesale markets [31]. Since this would require a large-scale demonstrator, this technology has not yet been deployed on a larger scale for energy markets.

- Peer-to-peer trading agents: This allows different types of energy market members to take part in transactions, including the current actors, as well as smaller actors, such as domestic customers. While peer-to-peer communication is widely used, for technologies, such as file-sharing, like blockchain, the application of peer-to-peer trading agents, especially for the energy system, has not been demonstrated yet on a larger scale [42].

- Generation Optimisation: Currently, each generator optimizes their assets with respect to market signals and predictions. In large-scale generation optimization, generation assets could be used in a more efficient way through real-time optimization. As there is currently limited information about real-time demand forecasting, specifically at lower meter classifications, this has not been demonstrated yet on larger scale [43].

- Virtual Power Plant: Aggregating a number of different generation, storage and demand assets into one heterogeneous distributed energy source through the use of cloud-based services in order to take part as one in energy wholesale markets. There are encouraging developments in VPPs accessing balancing and ancillary services markets [44].

\subsection{Technology Gaps to be Overcome to Enable Future Business Models}

In Section 3, we provided an overview of the relevant technologies for future electricity systems, their technology readiness levels and whether there are major barriers in the overcoming of these. In this section, we connect this back to the five energy system business model archetypes. For this, we outlined how crucial the technologies are, for these archetypes that are not yet in TRL 7-9 (see Table 6).

First, the archetype Low carbon transmission capacity provider, which is the closest to the current status quo, does not face any technological barriers at the moment. This is obvious, as this model does not require a change of the current centralized electricity market and system.

The archetypes New Electrifier, Serviced Home and Mobility and Third party control all imply a transition to more decentralized and, due to the increased amount of actors, to a more automated energy system. Therefore, the lack in maturity in technologies such as communication for wholesale markets, generation optimisation and virtual power plants play a crucial role for the implementation of such models. Currently, the technology, while deployed in trials, is not demonstrated on the larger scale. 
In comparison to these three archetypes, the archetype with the biggest challenge is the Peer to Peer 2.0 business archetype, as it faces the same issues as the latter three archetypes, as well as relies on the demonstration of a robust and reliable peer-to-peer trading infrastructure for energy markets.

To summarize, the technologies that have emerged as not being at a state of major deployment, are mainly integration and system technologies that require large scale demonstrators or deployment to be of TRL 7-9. In contrast, the results from Section 3.1 show that none of the energy supply or energy demand technologies require further research to make them technologically viable. We have not assessed economic or political viability.

Table 6. Technological barriers that need to be overcome for future energy systems business models.

\begin{tabular}{|c|c|c|c|c|c|c|c|}
\hline & Survey & sults & & & Archetype & & \\
\hline Technologies & $\begin{array}{c}\text { (A) } \\
\text { Technology } \\
\text { Readiness level } \\
\text { (TRL) } \\
\text { (Colour Code } \\
\text { outlines TRL level) } \\
1-3 \text { red } \\
4-6 \text { amber } \\
\text { 7-9 green }\end{array}$ & $\begin{array}{c}\text { (B) } \\
\text { Constraints/ } \\
\text { Barriers/Limits } \\
\text { to increase TRL } \\
\text { to 7-9 } \\
\text { (Colour code } \\
\text { illustrates how } \\
\text { easy to } \\
\text { overcome) } \\
\text { simple—green } \\
\text { medium-amber } \\
\text { difficult_red }\end{array}$ & 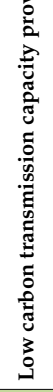 & 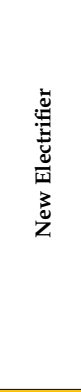 & 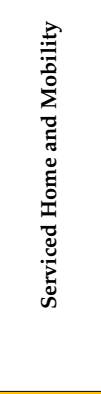 & 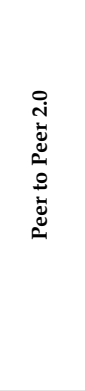 & 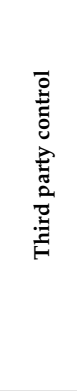 \\
\hline $\begin{array}{c}\text { Communication for } \\
\text { Wholesale market } \\
\text { [31] }\end{array}$ & $4-6$ & medium & less & crucial & crucial & crucial & crucial \\
\hline $\begin{array}{c}\text { Peer-to-peer } \\
\text { trading agents } \\
{[34]}\end{array}$ & $4-6$ & medium & $\mathbf{n} / \mathbf{r}$ & $\mathbf{n} / \mathbf{r}$ & less & crucial & less \\
\hline $\begin{array}{c}\text { Adv. Distribution } \\
\text { Management } \\
\text { System (ADMS) } \\
{[36]}\end{array}$ & $4-6$ & simple & less & less & less & less & less \\
\hline $\begin{array}{c}\text { M2M } \\
\text { Communications } \\
{[38]}\end{array}$ & $4-6$ & simple & less & less & less & less & less \\
\hline $\begin{array}{c}\text { Generation } \\
\text { Optimisation }\end{array}$ & $4-6$ & medium & less & crucial & crucial & crucial & crucial \\
\hline $\begin{array}{c}\text { Wide-Area Energy } \\
\text { Management } \\
\text { Systems (WAEMS) } \\
{[39]}\end{array}$ & $4-6$ & simple & less & crucial & crucial & less & less \\
\hline $\begin{array}{c}\text { Virtual Power } \\
\text { Plant (VPP) } \\
{[40]}\end{array}$ & $4-6$ & medium & less & crucial & crucial & crucial & crucial \\
\hline
\end{tabular}

${ }^{1}$ Description of Archetype-Technology link: Colour code illustrates whether a technology creates a bottleneck for the particular archetype, based upon (A) TRL, (B) how easy it can mature and (C) how relevant the technology is for the archetype). Not relevant-no colour; less important/crucial technology that is ready, or can be made ready easily—green; less important technology that is not ready yet, and that needs effort-light green; crucial technlogy that requires some effort to be ready-amber; crucial technology that requires significant effort to be made ready or that will not reach high TRLs_-red.

\section{Conclusion}

In this work, we conducted an analysis of energy system technologies that will be needed for future energy system using an expert panel approach to obtain TRLs for key enabling elements of new business models.

Our work shows the technologies that are needed to achieve the transition to novel business models in future energy systems. Furthermore, we outline whether these are technologically mature. Here, we can conclude that most of the technologies are already at a stage that they can be deployed widely, hence will not require research and development, nor deployment activities on a major scale.

However, there is still a set of energy system integration technologies that require major demonstrators or deployment programs in order to reach higher TRLs. These are the technologies: 
Communication for wholesale markets, peer-to-peer trading agents, generation optimisation and virtual power plant, all of which need a minimum scale to reach a higher maturity.

In order to do so, we recommend the creation of a set of large-scale demonstrators or one major demonstrator where these technologies are deployed on a regional level. Ofgem's Sandbox [45], the UK Research and Innovation Smart local energy systems demonstrators the Energy System Catapults Energy Town programs could be suitable means in the UK.

Conversely, we believe that the other technologies listed in the results do not require significant further R\&D investment by policy makers. We conclude that further basic research and development in these technologies is not critical to the transition towards sustainable future energy systems.

These twin statements, if verified by replicated studies, should lead to a new phase in supporting energy systems innovation. It is not that further developments in, for example, offshore wind efficiency or solar cell development are unlikely, it is simply that the returns on public innovation support in these areas may be diminishing or at least outstripped by the potential for systems innovation that support specific business models more towards the consumer end of the supply chain. These close to customer innovations such as peer-to-peer contracts and incentives for flexibility require a different innovation ecosystem described by iterative trials aimed at system optimisation.

Author Contributions: Christoph Mazur designed the study. Christoph Mazur, Jeffrey Hardy and Stephen Hall collected the survey inputs and analyzed them. Christoph Mazur, Jeffrey Hardy, Stephen Hall and Mark Workman analyzed the results, and wrote the paper.

Funding: This work was supported by the Energy Research Partnership and Energy Systems Catapult Utility 2050 project. Part of this work was supported by the Engineering and Physical Sciences Research Council under grant Ref: EP/N029488/1.

Acknowledgments: Thanks to the valuable feedback from the reviewers.

Conflicts of Interest: The authors declare no conflict of interest.

\section{References}

1. World Economic Forum. The Future of Electricity: New Technologies Transforming the Grid Edge; World Economic Forum: Cologny, Switzerland, 2017.

2. MIT Energy Initiative. Utility of the Future: An MIT Energy Initiative Response to an Industry in Transition. Available online: https:/ / energy.mit.edu/wp-content/uploads/2016/12/Utility-of-the-Future-Full-Report. pdf (accessed on 26 November 2018).

3. Foxon, T.J.; Hammond, G.P.; Pearson, P.J.G. Developing transition pathways for a low carbon electricity system in the UK. Technol. Forecast. Soc. Chang. 2010, 77, 1203-1213. [CrossRef]

4. ERP UK. ERP Utility2050 Project Interim Update. 2016. Available online: http:/ /erpuk.org/wp-content/uploads/ 2016/10/Utility-2050-ERP-Plenary-Presentation-11-Oct-WEBSITE.pdf (accessed on 26 November 2018).

5. Wegner, M.-S.; Hall, S.; Hardy, J.; Workman, M. Valuing energy futures; a comparative analysis of value pools across UK energy system scenarios. Appl. Energy 2017, 206, 815-828. [CrossRef]

6. Osterwalder, A.; Pigneur, Y. Business Model Generation: A Handbook for Visionaries. Game Changers, and Challangers; John Wiley \& Sons: Hoboken, NJ, USA, 2010.

7. Zott, C.; Amit, R.; Massa, L. The business model: Recent developments and future research. J. Manag. 2011. [CrossRef]

8. Christensen, C.M.; Bartman, T.; Van Bever, D. The Hard Truth About Business Model Innovation. Harvard Bus. Rev. 2016. [CrossRef]

9. Bryant, S.T.; Straker, K.; Wrigley, C. The typologies of power: Energy utility business models in an increasingly renewable sector. J. Clean. Prod. 2018. [CrossRef]

10. Hall, S.; Roelich, K. Business model innovation in electricity supply markets: The role of complex value in the United Kingdom. Energy Policy 2016, 92, 286-298. [CrossRef]

11. Engelken, M.; Römer, B.; Drescher, M.; Welpe, I.M.; Picot, A. Comparing drivers. barriers, and opportunities of business models for renewable energies: A review. Renew. Sustain. Energy Rev. 2016. [CrossRef]

12. Zarakas, W.P. Two-sided markets and the utility of the future: How services and transactions can shape the utility platform. Electr. J. 2017. [CrossRef] 
13. Bolton, R.; Hannon, M. Governing sustainability transitions through business model innovation: Towards a systems understanding. Res. Policy 2016. [CrossRef]

14. Reddy, S.; Painuly, J.P. Diffusion of renewable energy technologies-barriers and stakeholders' perspectives. Renew. Energy 2004, 29, 1431-1447. [CrossRef]

15. Zeng, M.A. Foresight by online communities-The case of renewable energies. Technol. Forecast. Socl Chang. 2018. [CrossRef]

16. Foxon, T.J.; Gross, R.; Chase, A.; Howes, J.; Arnall, A.; Anderson, D. UK innovation systems for new and renewable energy technologies: Drivers, barriers and systems failures. Energy Policy 2005, 33, 2123-2137. [CrossRef]

17. Pezzutto, S.; Grilli, G.; Zambotti, S.; Dunjic, S.; Pezzutto, S.; Grilli, G.; Zambotti, S.; Dunjic, S. Forecasting Electricity Market Price for End Users in EU28 until 2020-Main Factors of Influence. Energies 2018, 11, 1460. [CrossRef]

18. Mankins, J.C. Technology Readiness Levels. White Paper April 1995, 5. [CrossRef]

19. Mankins, J.C. Technology readiness assessments: A retrospective. Acta Astronaut. 2009, 65, 1216-1223. [CrossRef]

20. European Commission. Technology Readiness Levels (TRL). In HORIZON 2020—WORK PROGRAMME 2014-2015 General Annexes, Extract from Part 19-Commission Decision C; European Commission: Brussels, Belgium, 2014; p. 4995.

21. DeValve, T.; Olsommer, B. Micro-CHP Systems for Residential Applications; Elsevier: New York, NY, USA, 2007.

22. Ridjan, I.; Vad, B.; Connolly, D.; Dui, N. The feasibility of synthetic fuels in renewable energy systems. Energy 2013, 57, 76-84. [CrossRef]

23. Lund, H.; Werner, S.; Wiltshire, R.; Svendsen, S.; Thorsen, J.E.; Hvelplund, F.; Mathiesen, B.V. 4th Generation District Heating (4GDH). Energy 2014, 68, 1-11. [CrossRef]

24. Flourentzou, N.; Agelidis, V.G.G.; Demetriades, G.D.D. VSC-Based HVDC Power Transmission Systems: An Overview. IEEE Trans. Power Electron. 2009, 24, 592-602. [CrossRef]

25. Han, C.; Huang, A.; Baran, M.E.; Bhattacharya, S.; Litzenberger, W.; Anderson, L.; Johnson, A.L.; Edris, A.-A. STATCOM Impact Study on the Integration of a Large Wind Farm into a Weak Loop Power System. IEEE Trans. Energy Convers. 2008, 23, 226-233. [CrossRef]

26. Farhangi, H. The path of the smart grid. IEEE Power Energy Mag. 2010, 8, 18-28. [CrossRef]

27. Little, M.; Thomson, M.; Infield, D. Electrical integration of renewable energy into stand-alone power supplies incorporating hydrogen storage. Int. J. Hydrog. Energy 2007, 32, 1582-1588. [CrossRef]

28. Zhou, B.; Li, W.; Chan, K.W.; Cao, Y.; Kuang, Y.; Liu, X.; Wang, X. Smart home energy management systems: Concept, configurations, and scheduling strategies. Renew. Sustain. Rev. 2016, 61, 30-40. [CrossRef]

29. Park, K.; Kim, Y.; Kim, S.; Kim, K.; Lee, W.; Park, H. Building Energy Management System based on Smart Grid. In Proceedings of the 2011 IEEE 33rd International Telecommunications Energy Conference (INTELEC), Amsterdam, The Netherlands, 9-13 October 2011; pp. 1-4. [CrossRef]

30. Mazur, C. Electricity Demand-Side Response POSTnote 452. UK Parliament. Available online: http:// researchbriefings.parliament.uk/ResearchBriefing/Summary/POST-PN-452 (accessed on 26 November 2018).

31. Wang, Q.; Zhang, C.; Ding, Y.; Xydis, G.; Wang, J.; Østergaard, J. Review of real-time electricity markets for integrating Distributed Energy Resources and Demand Response. Appl. Energy 2015, 138, 695-706. [CrossRef]

32. Dixon, J.; Moran, L.; Rodriguez, J.; Domke, R. Reactive Power Compensation Technologies: State-of-the-Art Review. Proc. IEEE 2005, 93, 2144-2164. [CrossRef]

33. Siti, M.W.; Nicolae, D.V.; Jimoh, A.A.; Ukil, A. Reconfiguration and Load Balancing in the LV and MV Distribution Networks for Optimal Performance. IEEE Trans. Power Deliv. 2007, 22, 2534-2540. [CrossRef]

34. MacKie-Mason, J.K.; Wellman, M.P. Chapter 28 Automated Markets and Trading Agents. In Handbook of Computational Economics; Elsevier: Amsterdam, The Netherlands, 2006; Volume 2, pp. 1381-1431.

35. Eisenmann, T.; Parker, G.; Van Alstyne, M.W. Strategies for two-sided markets. Harv. Bus. Rev. 2006. [CrossRef]

36. Fan, J.; Borlase, S. The evolution of distribution. IEEE Power Energy Mag. 2009, 7, 63-68. [CrossRef]

37. Caramanis, M.; Ntakou, E.; Hogan, W.W.; Chakrabortty, A.; Schoene, J. Co-optimization of power and reserves in dynamic T\&D power markets with nondispatchable renewable generation and distributed energy resources. Proc. IEEE 2016. [CrossRef] 
38. Makarov, Y.V.; Yang, B.; DeSteese, J.G.; Lu, S.; Miller, C.H.; Nyeng, P.; Ma, J.; Hammerstrom, D.J.; Vishwanathan, V.V. Wide-Area Energy Storage and Management System to Balance Intermittent Resources in the Bonneville Power Administration and California ISO Control Areas; Pacific Northwest National Lab.: Richland, WA, USA, 2008.

39. Pudjianto, D.; Ramsay, C.; Strbac, G. Virtual power plant and system integration of distributed energy resources. IET Renew. Power Gener. 2007, 1, 10-16. [CrossRef]

40. Geels, F.W.; Sovacool, B.K.; Schwanen, T.; Sorrell, S. The Socio-Technical Dynamics of Low-Carbon Transitions. Joule 2017. [CrossRef]

41. Geels, F.W.; Sovacool, B.K.; Schwanen, T.; Sorrell, S. The Socio-Technical Dynamics of Low-Carbon Transitions. Joule 2017. [CrossRef]

42. Morstyn, T.; Teytelboym, A.; McCulloch, M.D. Bilateral Contract Networks for Peer-to-Peer Energy Trading. IEEE Trans. Smart Grid 2018. [CrossRef]

43. Yu, Z; ; Dexter, A. Online tuning of a supervisory fuzzy controller for low-energy building system using reinforcement learning. Control Eng. Pract. 2010. [CrossRef]

44. Coyne. Limejump Now Trading Flex in the Balancing Mechanism. 2018. Available online: https:// theenergyst.com/limejump-now-trading-flex-balancing-market (accessed on 26 November 2018).

45. Ofgem. The Innovation Link / Ofgem. 2018. Available online: https://www.ofgem.gov.uk/about-us/howwe-engage/innovation-link (accessed on 23 November 2018).

(C) 2019 by the authors. Licensee MDPI, Basel, Switzerland. This article is an open access article distributed under the terms and conditions of the Creative Commons Attribution (CC BY) license (http://creativecommons.org/licenses/by/4.0/). 